PNNL-24097

LA-UR 14-27161

\title{
Climate Change and the Los Alamos National Laboratory: The Adaptation Challenge
}

Kim M. Fowler, Pacific Northwest National Laboratory

Josh Silverman, U.S. Department of Energy

Denny L. Hjeresen, Los Alamos National Laboratory

February 2015

Prepared for the U.S. Department of Energy

under Contract DE AC05 76RL01830

Pacific Northwest National Laboratory

Richland, Washington 99352
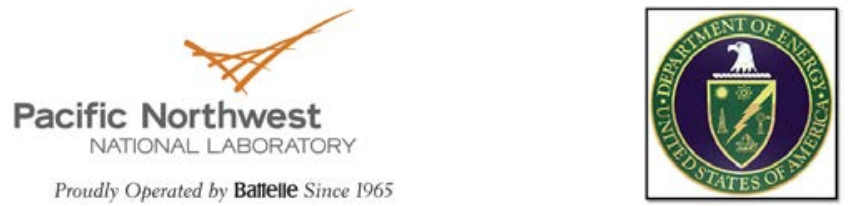

Los Alamos

NATIONAL LABORATORY 
PNNL-24097

LA-UR 14-27161

\section{DISCLAIMER}

This report was prepared as an account of work sponsored by an agency of the United States Government. Neither the United States Government nor any agency thereof, nor Battelle Memorial Institute, nor any of their employees, makes any warranty, express or implied, or assumes any legal liability or responsibility for the accuracy, completeness, or usefulness of any information, apparatus, product, or process disclosed, or represents that its use would not infringe privately owned rights. Reference herein to any specific commercial product, process, or service by trade name, trademark, manufacturer, or otherwise does not necessarily constitute or imply its endorsement, recommendation, or favoring by the United States Government or any agency thereof, or Battelle Memorial Institute. The views and opinions of authors expressed herein do not necessarily state or reflect those of the United States Government or any agency thereof.

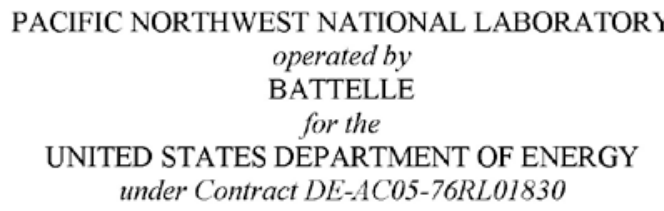

Printed in the United States of America

Available to DOE and DOE contractors from the Office of Scientific and Technical Information,

P.O. Box 62, Oak Ridge, TN 37831-0062;

ph: (865) 576-8401

fax: $(865) 576-5728$

email: reports $a$ adonis.osti.gov

Available to the public from the National Technical Information Service

5301 Shawnee Rd., Alexandria, VA 22312

ph: (800) 553-NTIS (6847)

email: ordersantis.gov <http://www.ntis.gov/about/form.aspx $>$

Online ordering: http://www.ntis.gov 
The Los Alamos National Laboratory (LANL) has been adapting to climate change related impacts that have been occurring on decadal time scales. The region where LANL is located has been subject to a cascade of climate related impacts: drought, devastating wildfires, and historic flooding events. Instead of buckling under the pressure, LANL and the surrounding communities have integrated climate change mitigation strategies into their daily operations and long-term plans by increasing coordination and communication between the Federal, State, and local agencies in the region, identifying and aggressively managing forested areas in need of near-term attention, addressing flood control and retention issues, and more.

\section{Overview}

LANL is a Department of Energy (DOE) national laboratory located in the high desert of Northern New Mexico, 35 miles northwest of Santa Fe at an elevation of 7,320 feet. The area averages 19 inches of rain and over 55 inches of snow annually. Seven watersheds drain from LANL into the Rio Grande. LANL has 1,280 buildings covering 9 million square feet -8 of which are high/moderate nuclear facilities -268 miles of roads, 139 miles of $115-\mathrm{KV}$ and 13.2-KV electrical lines, 58 miles of gas lines, and its own power plant. The site holds several metric tons of nuclear material and approximately 140,000 chemical containers.

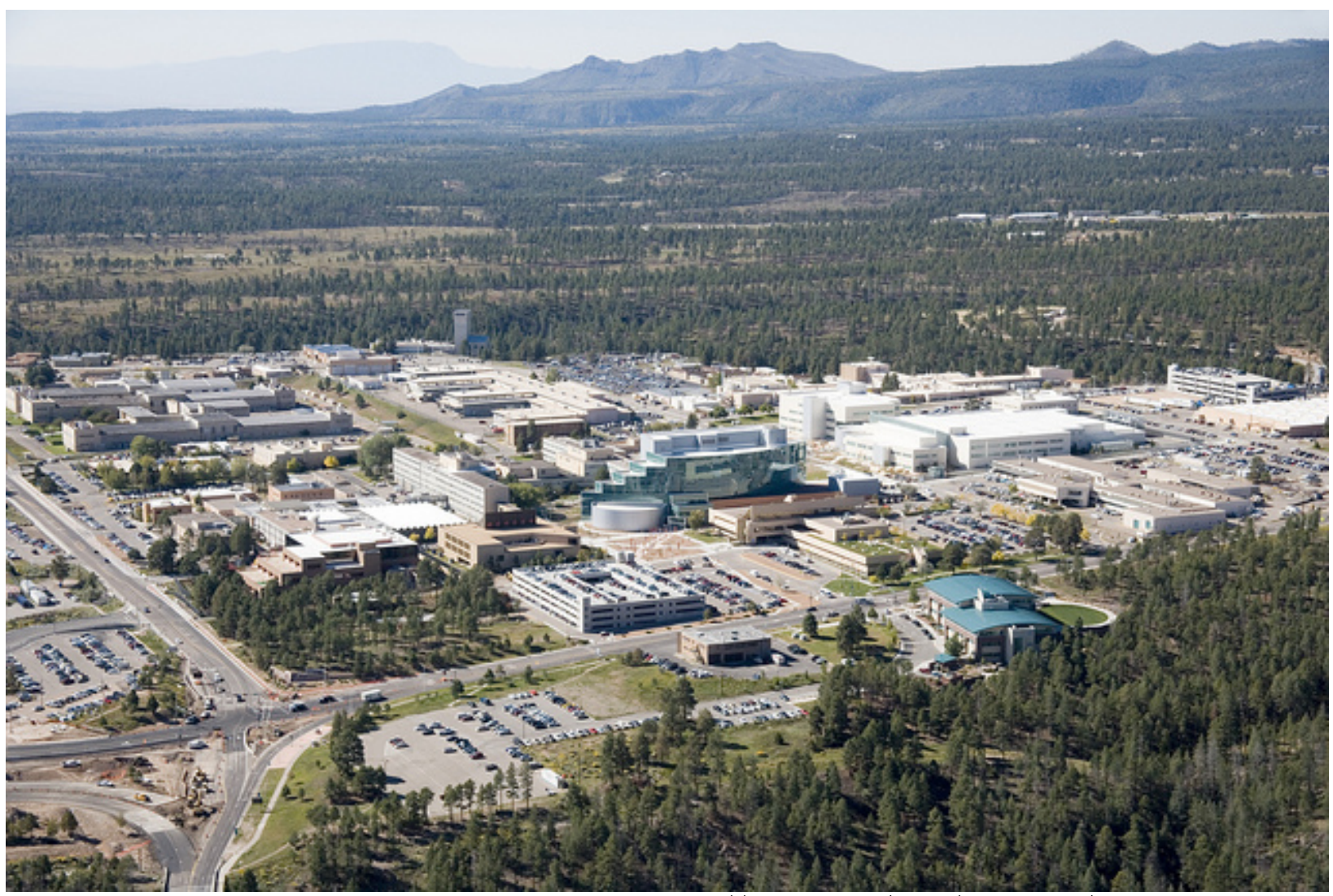

Figure 1. Aerial view of LANL's technical area (source: http://www.lanl.gov/about/facts-figures/location.php)

LANL's mission is "to solve national security challenges through scientific excellence." The workforce numbered over 11,000 in 2015. The cities of Los Alamos and White Rock are the bedroom communities of the Laboratory with approximately 12,000 inhabitants according to the 2010 census. There is also an extensive commuting workforce from throughout Northern New Mexico. The Laboratory and these communities are surrounded by the Santa Fe National Forest, the San Ildefonso Indian Reservation, and Bandelier National Monument. 
PNNL-24097

LA-UR 14-27161

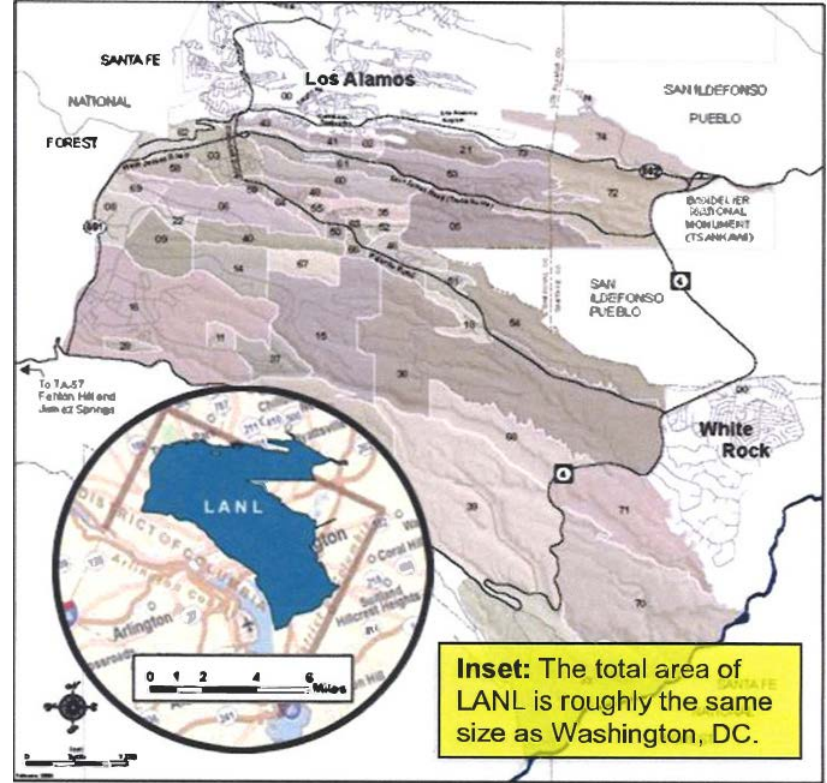

Figure 2. LANL Site Footprint (source: Climate Change and Infrastructure Planning presentation [LA-UR 14-27161])

\section{Cascading Climate Impacts}

Climate-related impacts are often far-reaching, diffuse, incremental and interrelated. Individual impacts spread over several decades challenge typical infrastructure planning methodologies that are responsive to events but rarely anticipatory. Climate variability on the Pajarito Plateau is nothing new and has affected human populations over a thousand years. However, the most recent cycle of drought, fire, and flood events is illustrative of the cumulative impacts of climate variability. The 1980's saw a relatively wet weather pattern with normal monsoon rainfall and heavy winter snowpack supporting a steady river runoff in the spring and early summer. This period saw an increase in forest fuel loading coupled with aggressive fire suppression efforts when wildfires began. The early 1990's saw the beginning of a severe drought that has persisted for over 20 years. Deteriorating forest health opened

a path for a widespread infestation of pine bark beetles. An outbreak-level infestation occurred in the 20022004 timeframe killing millions of trees over 2.1 million acres of piñon-juniper forest and 1.3 million acres of Ponderosa pine forest in Arizona and New Mexico. The combination of extensive understory growth in the 1980's, the lack of natural burns, dead combustible trees, higher temperatures and dry winds set the stage for the first of the megafires to hit the Pajarito Plateau.

\section{Megafires}

Wildfires are common in a high desert environment. From 2000 through 2013 the State of New Mexico fire acreage burned is variable, but the number of acres burned has increased significantly in recent years. When considering the major fires near the Los Alamos area there has been a dramatic increase in acres burned per fire:

- June 1954 - Water Canyon fire: 3,000-6,000 acres

- June 1977 - La Mesa fire: 15,000 acres

- April-May 1996 - Dome fire: 16,000 acres

- June-July 1998 - Oso fire: 5,000 acres

- $\quad$ May 2000 - Cerro Grande fire: 43,000-48,000 acres

- June - August 2011 - Las Conchas fire: 154,000 acres

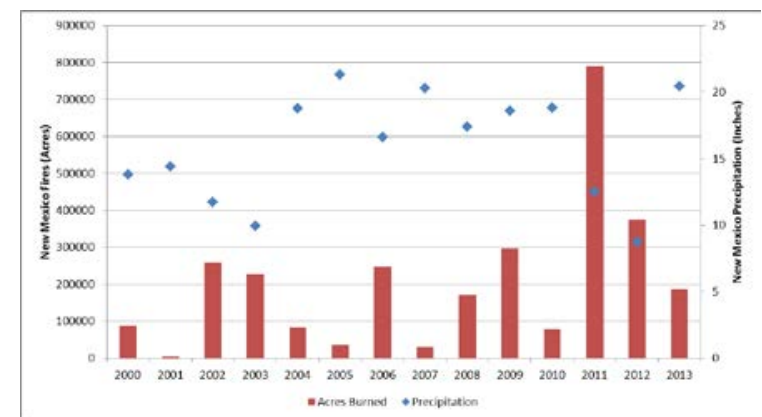

Figure 3. State of New Mexico fires and precipitation (2000-2013)

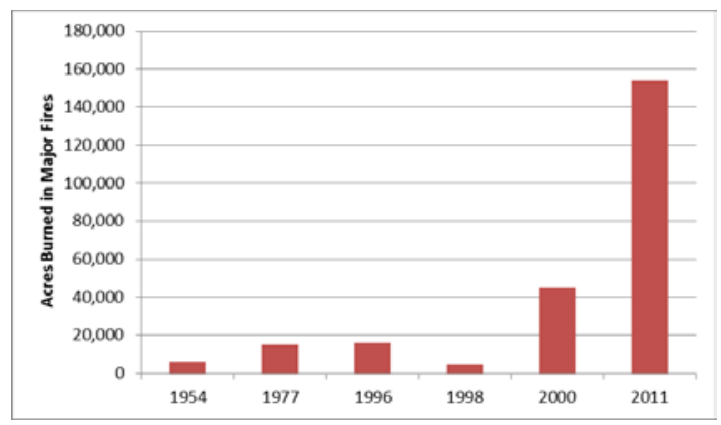

Figure 4. Major fires in Los Alamos area over the last 50 years 
Megafires are fires that are large, have highly unpredictable behavior and are characterized by the impact on human environments and extreme ecological damage, such as destroying homes and/or destroying forest vegetation including that needed to repropagate lost trees. The first of the megafires to affect LANL was the 2000 Cerro Grande fire, which burned 43,00048,000 acres in the surrounding Santa Fe

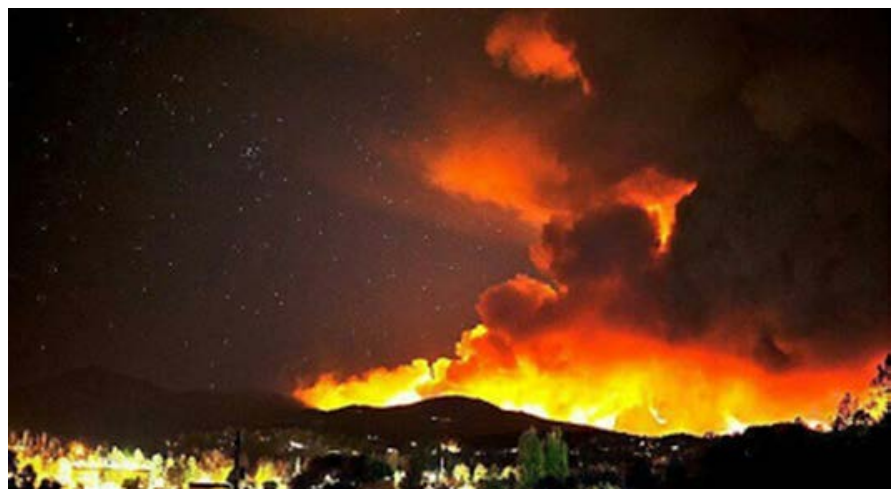

Figure 5: Cerro Grand Fire (source: Climate Change and Infrastructure Planning presentation [LA-UR 14-27161]) causing $\$ 1$ billion in damages within the fire area including the loss of 45 LANL buildings with 67 more damaged, loss of 235 homes in the surrounding communities, displacing over 400 families, and damaging many other structures. At the time, it was the largest forest fire in the region's history.

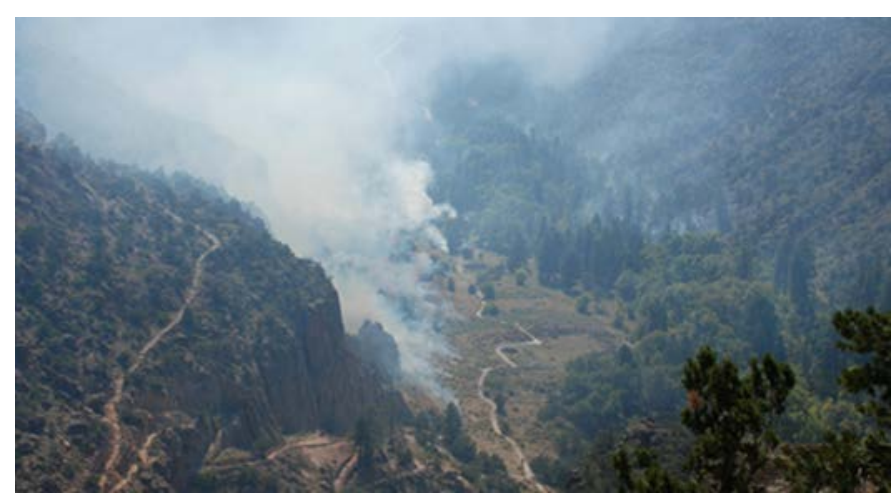

Figure 6. Controlled Burn on May 4, 2000 (source: Climate Change and Infrastructure Planning presentation [LA-UR 14-27161])
The Cerro Grande fire began as a planned burn of up to 900 acres by the National Park Service in the Bandelier National Monument to reduce vegetative buildup. A General Accounting Office lessons learned report about the fire identified that the timing of the planned burn was at the beginning of the fire season which is also a time for high winds in the region, the area was in the middle of a persistent drought, and 4 other controlled burns in the region had already gotten out of control. The tactic of creating backlines as a firebreak with insufficient wind speed and direction information compounded the impact of the fire as it moved toward LANL and the communities of Los Alamos and White Rock.

LANL was evacuated and shut down from May $8^{\text {th }}$ through May 22 ${ }^{\text {nd }}$. Approximately 7,500 acres of LANL property was burned affecting operational readiness in 237 structures with 67 buildings damaged and 45 buildings destroyed, mostly office trailers and small storage sheds. No structures with radioactive or chemical inventories burned and none of the damaged and destroyed properties were identified as major buildings. The fire burned over 308 potential release sites (PRSs) and areas known to have low levels of surface contamination. None of these sites released measurable contaminants,

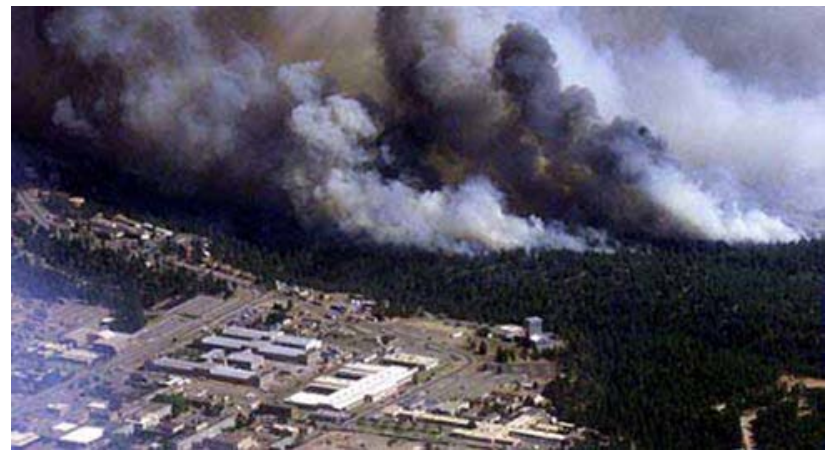

Figure 7. Cerro Grande Fire near LANL property on May 7, 2000 (source: Climate Change and Infrastructure Planning presentation [LA-UR 14-27161]) however, 91 of the PRSs needed to address increased erosion potential following the fire. Damages to the Laboratory totaled $\$ 331$ million not including lost productivity. 
PNNL-24097

LA-UR 14-27161

Once the fire season ends the concern shifts toward flooding and erosion. During the monsoon season (July-August), mitigation measures are generally taken to minimize potential impacts from heavy rains, but the intensity of the season is likely to determine the level of damage. Immediately following the Cerro Grande fire, LANL built a temporary dry dam to protect the Los Alamos Critical Experiments Facility (Technical Area 18) from potential flash floods and within two years completely moved all mission activities out of what was identified to be a vulnerable site. Similar actions were taken at Technical Area 2 in a different canyon below the Los Alamos town site. Community organizations also worked rapidly to address erosion concerns. Approximately 1,600 acres were covered with hydro-mulching and hydro-seeding to speed up the re-vegetation process, trees were planted through community volunteer efforts, trails were repaired, and mulch was applied to slopes to minimize erosion and facilitate regrowth. Fortunately, the monsoon season in 2000 was mild, so no major floods occurred.

LANL had made efforts prior to the Cerro Grande fire to mitigate risks, by thinning forests near critical facilities and other related measures. But the fire served as a wakeup call for how costly and extreme the risks could be. Given the fuel availability, temperature, precipitation, wind, humidity, lightning strike locations, and the increase in population density, New Mexico could expect to have a greater number of more intense wildfires in the future unless mitigation strategies were implemented. The Cerro Grande fire underscored these risks and LANL undertook a concerted effort to enhance its climaterelated mitigation efforts by addressing key areas of concern:

- In keeping with the recommendations of numerous high-level climate reports, including the National Climate Assessment and the America's Climate Choices Final Report, LANL developed a "Long Term Strategy for Environmental Stewardship and Sustainability" that includes strategies to address its infrastructure needs for climate adaptation.

- Cultural resources have been rehabilitated since the Cerro Grande file and continue to be protected through vegetation removal, erosion control, and fencing.

- Critical areas, called 'fuel treatment plots,' have been identified and the fuel level is being managed by the 
Wildland Fire Mitigation team to pre-1900 levels of 50 to 150 trees per acre in order to minimize potential fire risks. Currently the forests tend to have 400 and 1,300 trees per acre; this tenfold increase in dead fuel load has led to the more intense crown fires rather than the historical low intensity surface fires that traditionally burned back the grassy understory and thinned out the new trees.

- Fire road and firebreak inspection programs have been implemented to foster better coordination/communication between Federal, State and local agencies present in the region.

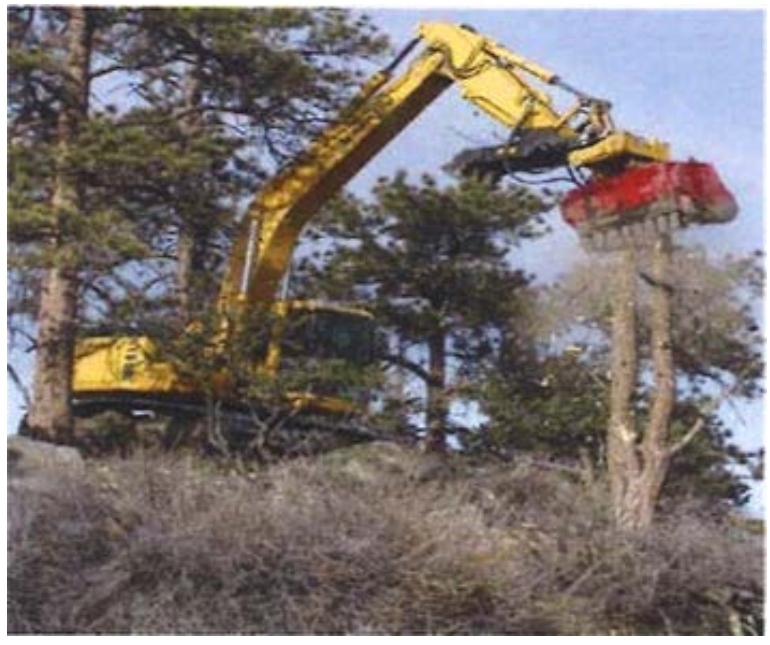

Figure 8. Fuels mitigation (source: Climate Change and Infrastructure Planning presentation [LA-UR 14-27161])

- Periodic removal of sediment from the Los Alamos Canyon Weir and other water retention areas, in response to and preparation for flooding and erosion.

- LANL proactively partnered with the Army Corps of Engineers to construct a 70-foot flood control and retention structure in Pajarito Canyon.

- Specific areas of concern have been protected with sheet piling, small retention basins, and diversion channels or culverts to increase stream capacity during a flash flood event.

- As a response to potential flooding, surface water management techniques shifted to low impact controls and away from more permanent concrete structures. This change was made in close cooperation with external stakeholders.

- Burned areas and slopes that could potentially slow down a flash flood have been seeded and willow trees have been planted in a wetland.

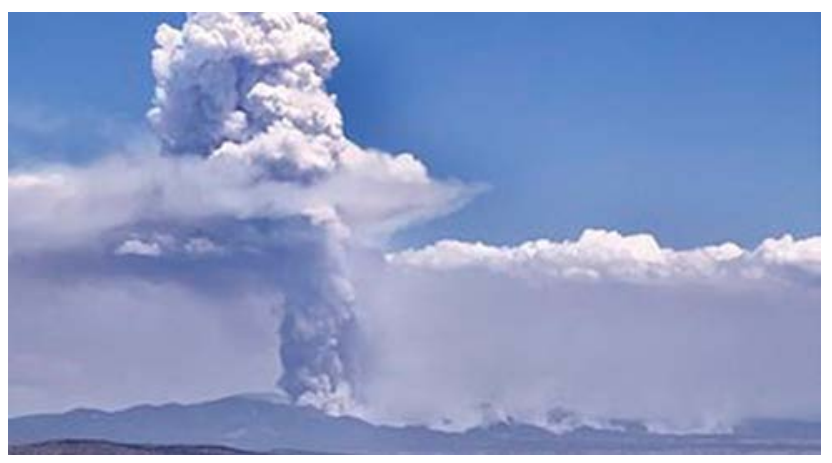

Figure 9. Las Conchas Fire July 6, 2011 from Placitas, NM (source: John Fowler)

LANL's efforts to prepare for climate-related environmental events have been repeatedly tested since the Cerro Grande fire by additional climate-related disasters that have caused considerable damage to LANL.

In 2011, LANL was hit again with a megafire and subsequent precipitation. From June $26^{\text {th }}$ through August $3^{\text {rd }}$, the Los Alamos area experienced the Las Conchas fire, the largest recorded wildfire in New Mexico history. It burned 154,000 acres, destroyed 63 structures, and cost an estimated $\$ 160$ million. However, preparations and mitigations following the Cerro Grande fire yielded a different outcome and direct Laboratory costs were estimated at $\$ 15.7$ million not including lost productivity. Although only one acre of operational LANL land was burned in this fire, the fire's intensity and proximity to the Laboratory resulted in a 9-day closure for all non-essential personnel. 


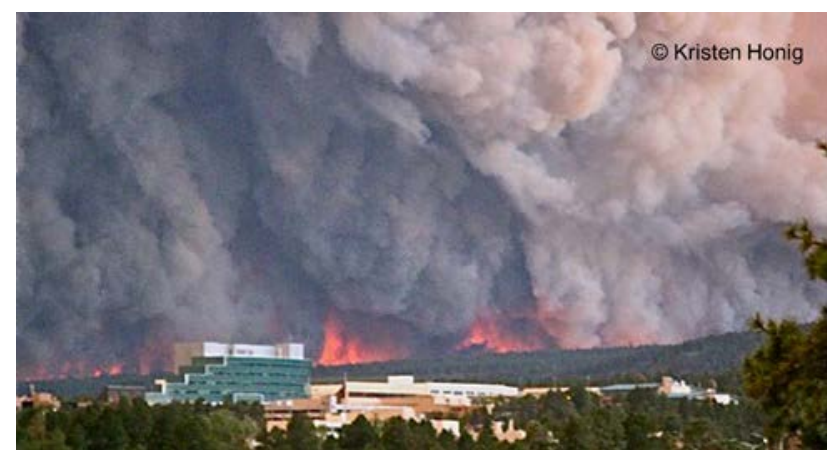

Figure 10. Las Conchas Fire (source: Climate Change and Infrastructure Planning presentation [LA-UR 14-27161])

\section{And then Flooding}

On August 21, 2011 the monsoon rains brought the feared flash flooding. The flooding intensity was significantly higher due to the Las Conchas fire depletion of vegetation and the creation of a hydrophobic (waxy) layer over the soil. The Park Service at Bandelier National Monument removed bridges so that they would not become dams in the event of a flash flood, water repellant material was placed on the outside walls of historic buildings, and sand bags were used to surround and protect key buildings. LANL immediately worked to prepare for expected flash flooding in order to minimize runoff from the Laboratory into the Rio Grande. Barriers were installed to divert the water to holding areas and sediment was removed from these holding

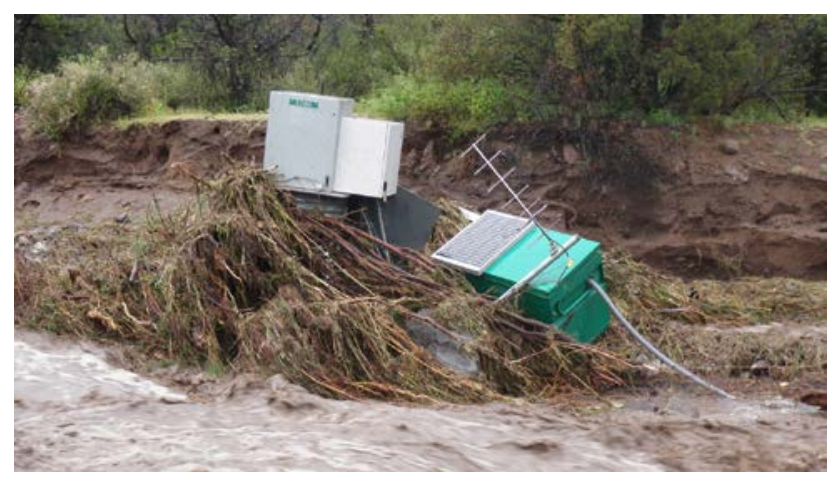

Figure 12. Contaminant Monitoring Station impacted by flooding (source: Climate Change and Infrastructure Planning presentation [LA-UR 14-27161])
The Las Conchas fire also resulted in a major shift in approach to transuranic waste storage and shipping at Los Alamos. The perceived risk of above ground storage of wastes at Technical Area 54 prompted the Laboratory and the State of New Mexico Environmental Department to reach agreement on the accelerated removal of 3706 cubic meters of stored aboveground transuranic waste from the site. This resulted in shifting of priorities from other cleanup activities; over $\$ 150$ million was reprioritized from the Lab's environmental programs to address the waste relocation.

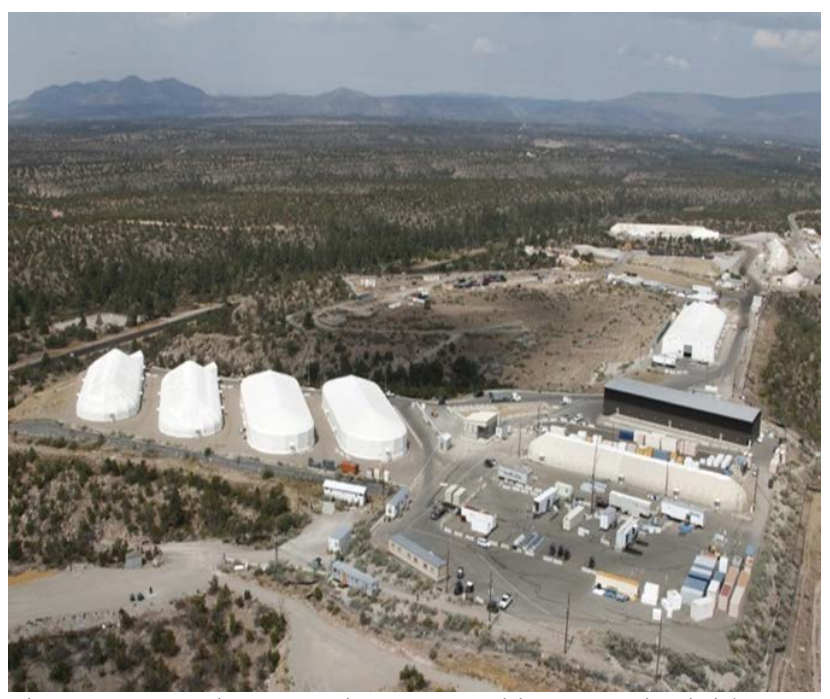

Figure 11. Moved transuranic waste to address perceived risk (source: Climate Change and Infrastructure Planning presentation [LA-UR 14-27161])

areas in order to better manage the flash flood water. Wells were sealed, waste drums were moved, and sampling stations were setup to test the runoff water for contaminants. The mitigation measures were successful in reducing the runoff damage from the 2011 flash floods. LANL developed additional plans to repair the property that was damaged in the 2011 floods and continue to deploy mitigation measures that have been proven to work. To help repair the stream banks and preserve the Pueblo Canyon wetland, LANL planted approximately 10,000 willow trees. 
However, the intensity of weather events has challenged even these preparations. In September 2013 Los Alamos received 450\% of average rainfall leading to ground saturation. On September 13, 2013 24-hour rain total were measured at 4-6 inches with some mountain locations recording 18 inches of rain in 24-hours. The resulting 1000-year rain event caused $\$ 17.4$ million in damage to environmental restoration infrastructure, monitoring gages, roadways and storm water control structures on LANL property alone. The floods created 1,000 meters of channels and eroded the stream banks of the Pueblo Canyon wetland, which is an important contaminated sediment stabilization system on the LANL site. This project

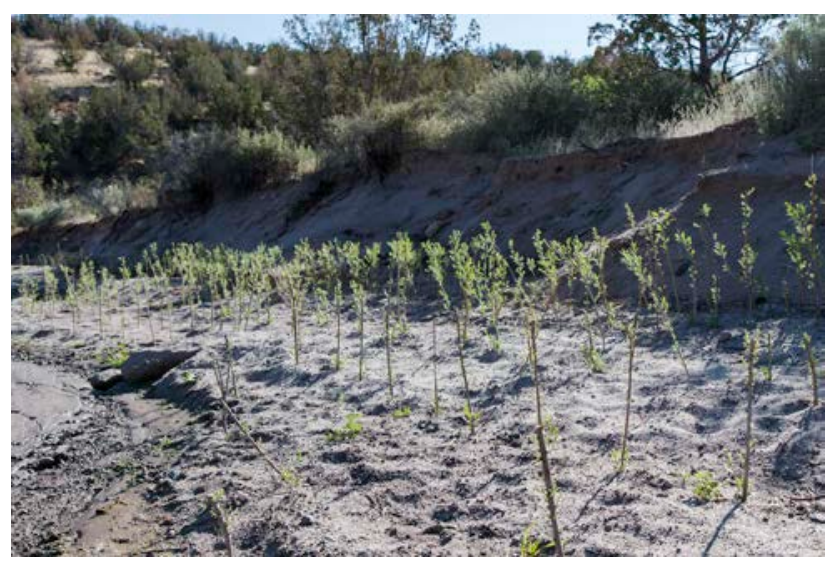

Figure 13. Willow planting for runoff speed abatement in Pueblo Canyon (source: http://www.lanl.gov/communityenvironment/environmental-stewardship/cleanup/cleanupfeatures/06.18-willows.php) is just one that LANL has planned to conduct flood recovery activities on up to 130 sites damaged in the flooding. Further, possible contaminant transport necessitates re-sampling within the canyons damaged by the flooding.

\section{Don't forget cold}

The high desert of Northern New Mexico is no stranger to winter weather, attested to by some great skiing, including Pajarito Mountain, 10 minutes from the center of Los Alamos. However, in February 2011 record cold was experienced across the Southwest. February $2^{\text {nd }}$ and $3^{\text {rd }}$ lows were -13 to $-15 \mathrm{~F}$ in Los Alamos. A cascade of events again affected Laboratory operations. Cold temperatures in Texas caused electricity and natural gas demand to spike while production facilities were taken off-line due to freezing. Blackouts further aggravated gas production causing shutdowns in multiple states. Northern New Mexico came to a standstill although separate Laboratory gas supplies remained intact. Pipes and infrastructure in dozens of Laboratory buildings froze causing work stoppages. As power and gas were restored, pipefitters and craft workers from LANL fanned out across the surrounding communities to help relight pilot lights and check power supplies. Burst water pipes in Laboratory buildings resulted in extensive damage as temperatures rose above freezing after nearly two weeks below zero. Recent "Polar Vortex" events across the U.S. followed this same weather pattern and indicate an ongoing vulnerability.

\section{Finally, the wind}

To mitigate fire danger, safety procedures at Los Alamos require cessation of outdoor operations such as explosives testing, environmental restoration, some construction and even fire mitigation activities under "Red Flag" conditions. Red Flag days are called when wind gusts exceed 20 miles per hour and the relative humidity drops below $15 \%$. As can be seen in Figure 14, such days are steadily increasing. This requires a new level of work planning that includes weather assessments.

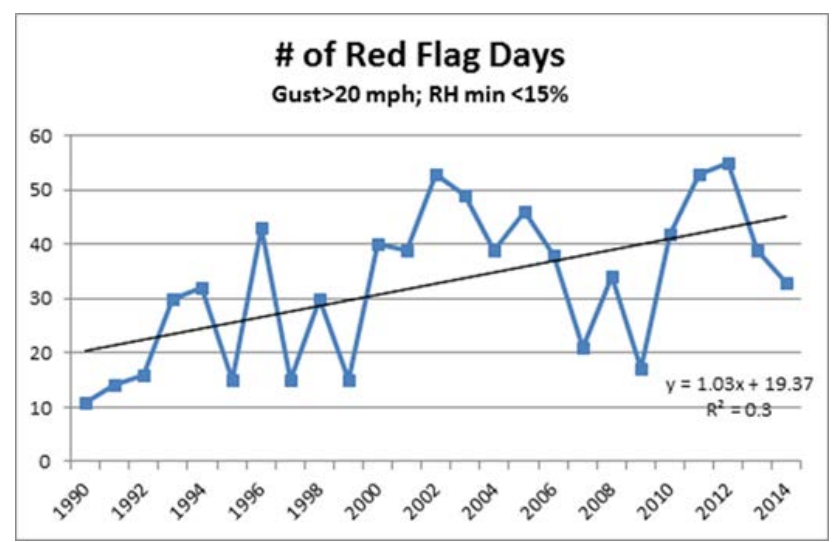

Figure 14. National Weather Service data on Red Flag conditions in Northern New Mexico. 
PNNL-24097

LA-UR 14-27161

\section{Responding and Preparing}

Over the last 15 years, LANL has been challenged with a barrage of fires, floods, and drought. Instead of being discouraged by these frequent climate-related disasters, the Laboratory has taken a proactive approach to identify strategies that will mitigate or at least minimize the long-and short-term effects of these events. LANL recognizes both the environmental and economic value to minimizing the effects of each event. The cost implications are substantial; a shut-down of the Laboratory costs an estimated $\$ 15$ million per week in lost productivity. In addition, the proactive measures LANL took to minimize climate impacts resulted in lower costs associated with cleaning up damaged property and resuming safe operations after the Las Conchas fire.

LANL has successfully worked with other Federal agencies and State and local governments to improve communication during events and restoration activities. The Laboratory has reduced the contamination risk by relocating contaminated materials and shipping transuranic waste off-site. To increase confidence in the surrounding communities in the Rio Grande river basin LANL has installed additional water quality monitors and has strategies in place to minimize contaminant runoff in the case of flash floods. Retention basins and grade-control structures have been created to reduce transport of contaminated sediment. Damaged areas have been re-seeded with groundcover and planted with trees to give the environment a fighting chance when the next event occurs. To keep focused attention on the subject the Laboratory appointed a Climate Adaptation Team Leader as part of its Long Term Strategy for Environmental Stewardship and Sustainability. Climate change is a significant challenge at the Los Alamos National Laboratory, but by integrating climate change mitigation strategies into facility operations and long-term planning the Lab can ensure it has the best opportunities to weather the storm.

\section{Key Considerations for Managers and Practitioners}

The efforts that LANL has taken to mitigate the impacts of climate-related effects on their site offer lessons for all DOE sites. Sites need to be aware of changing conditions in their regions so that they can understand how the climate-related risks may have changed, such as increase in event intensity, changes in frequency, and how multiple events could compound the impact.

- DOE sites should assess their specific operational vulnerabilities to ensure both continuity of operations and prevention of offsite impacts from climate events. For example, are there waste ponds or storage areas that could be compromised by an extreme storm event?

- DOE sites need to recognize that their climate-related risks include "beyond design-basis" events. Building on the lessons of the 2011 Fukushima Daiichi disaster, where multiple events compounded impacts of an unexpectedly large earthquake, DOE sites need to be aware of the 1000 -year event or worst case scenario, not just what has been experienced in recent times. DOE sites need to understand the probability of such events and how the probability of these events is anticipated to change over time.

- When considering the possible extreme events, consider the impacts and the external stakeholders that will need to be involved if such an event occurs. Build community relationships before extreme events happen. Strong networks and community partnerships improve organizational resilience.

- Look to balance an understanding of the full costs of an extreme event (including the cost of shutting down a DOE site and managing the public concerns over nuclear materials and waste) with actions that can be taken to minimize the impact at reasonable costs. Balance the cost of possible proactive remedies against the consequences of inaction prior to an extreme event in the planning process. 
- Remember that traditional practices (i.e., controlled burns) may need to be re-examined given changing conditions. Climate variations may introduce new risks into what are seen as "normal" activities. Familiar activities may not be as safe as they once were.

- Learn from experience and plan for the next event. Advance planning can help to avoid or at least mitigate the most severe consequences of major events. The Las Conchas fire would have been much more damaging to LANL had the Lab not addressed lessons learned from the Cerro Grande fire.

- Integrate climate considerations into existing emergency management and safety planning. Climate risks are not fundamentally different from the risks DOE sites already plan for, and can typically be addressed through thoughtful adjustments to existing risk management processes and systems. 
PNNL-24097

LA-UR 14-27161

\section{References:}

Bachelet, Dominique (Oregon State University), James Lenihan, and Ronald Neilson (U.S. Forest Service). 2007. Wildfires \& Global Climate Change: The Importance of Climate Change for Future Wildfire Scenarios in the Western United States. Excerpted from the full report, Regional Impacts of Climate Change: Four Case Studies in the United States prepared for the Pew Center on Global Climate Change. Arlington, Virginia.

County of Los Alamos, Los Alamos County Community Wildfire Protection, and Los Alamos Fire Department. 2009. Community Wildfire Protection Plan. Los Alamos, New Mexico.

Gentile, Bill and Kevin Leifheit. 2014. LANL Emergency Planning and Preparedness Overview. Presentation given June 4, 2104. Los Alamos National Laboratory. Los Alamos, New Mexico.

Hill, Barry. 2000. Fire Management: Lessons Learned From the Cerro Grande (Los Alamos) Fire. Statement prepared for a hearing before the Committee on Energy and National Resources, U.S. Senate, July 20, 2000. GAO/T-RCED-00-257. General Accounting Office. Washington, D.C.

Hjeresen, DL. 2014. Climate Change and Infrastructure Planning. Presentation given September 18, 2014, DOE Annual Sustainability Workshop, Albuquerque, N.M. LA-UR 14-27161. Los Alamos National Laboratory. Los Alamos, New Mexico.

LANL. 2000. A Special Edition of the SWEIS Yearbook Wildfire 2000. LA-UR-00-3471. Los Alamos National Laboratory. Los Alamos, New Mexico.

LANL. 2012. Long Term Strategy for Environmental Stewardship and Sustainability (http://www.lanl.gov/projects/long-term-environmental-strategy/). Accessed: January 19, 2015. LA-UR-1224845. Los Alamos National Laboratory. Los Alamos, New Mexico.

LANL. 2015. Location and Infrastructure. Website: http://www.lanl.gov/about/facts-figures/location.php. Accessed: January 19, 2015. Los Alamos National Laboratory. Los Alamos, New Mexico.

Noll, Phillip. 2014. Fiscal Year 2013 Mitigation Action Plan Annual Report for the 2008 Los Alamos National Laboratory Site-Wide Environmental Impact Statement. LA-UR-13-28416. Los Alamos National Laboratory. Los Alamos, New Mexico.

Valdez, Carlos. 2002. Bark Beetles in a Pine Nutshell. New Mexico State University Cooperative Extension Agent. Los Alamos, New Mexico.

Weather Warehouse. 2015. Los Alamos, New Mexico Weather Station Total Precipitation. Website: http://weatherwarehouse.com/WeatherHistory/PastWeatherData_LosAlamos_LosAlamos_NM_August.html. Accessed: January 19, 2015. 